\title{
ВІКОВІ ОСОБЛИВОСТІ РЕМОДЕЛЮВАННЯ М'ЯЗІВ ЯЗИКА У ЕКСПЕРИМЕНТАЛЬНИХ ТВАРИН ПРИ ДЕСКВАМАТИВНОМУ ГЛОСИТІ
}

\author{
๑І. В. Боднарчук , М. С. Гнатюк, Л. В. Татарчук \\ Тернопільський національний медичний університет імені І. Я. Горбачевського МОз України
}

РЕзЮМЕ. Десквамативний глосит - це запально-дистрофічне ураження слизових оболонки язика, яке локалізується переважно на спинці та бічних поверхнях вказаного органа. Найчастіше ця патологія трапляється при захворюваннях шлунково-кишкового тракту та кровотворної системи. Десквамативний глосит як самостійна патологія виявляється нерідко, а його діагностика нелегка.

Мета - вивчити вікові особливості ремоделювання м'язів язика при десквамативному глоситі.

Матеріал і методи. Комплексом морфологічних методів досліджені м'язи язика 60 лабораторних статевозрілих білих щурів-самців, які були поділені на 4-и групи. 1-а група нараховувала 15 8-місячних тварин, які знаходилися у звичайних умовах віварію, 2-а - 15 аналогічних 24-місячних щурів, 3-я - 15 8-місячних тварин із змодельованим десквамативним глоситом, 4-а - 15 24-місячних щурів із десквамативним глоситом. Мікротомні зрізи язика фарбували гематоксиліном-еозином, за Ван Гізон, Маллорі, толуїдиновим синім. Морфометрично визначали діаметр м'язових волокон, їх ядер, ядерно-цитоплазматичні відношення у цих структурах, відносні об'єми строми, м'язів, стромально-міоцитарні відношення, відносний об'єм пошкоджених м'язових волокон. Гістологічні препарати досліджували також у поляризованому світлі. Кількісні показники обробляли статистично.

Результати. Встановлено, що десквамативний глосит у лабораторних білих щурів-самців, крім ремоделювання структур слизової оболонки, призводить до морфологічної перебудови м'язів язика, яка характеризується помірною атрофією, порушенням тканинного та клітинного структурних гомеостазів, зростанням відносного об'єму пошкоджених м'язових волокон, дистрофією, некробіозом та їх контрактурними пошкодженнями, інфільтрацією і склерозуванням. Ступінь ремоделювання м'язів язика домінував у верхньому поздовжньому м'язі та у дослідних тварин старшої вікової групи. Останнє підтверджувалося відносними об'ємами пошкоджених м'язових волокон, який у молодих щурів дорівнював $(12,40 \pm 0,15) \%$, а у старих $-(19,60 \pm 0,18) \%(p<0,001)$.

Висновки. Десквамативний глосит у лабораторних білих щурів-самців, крім ремоделювання структур слизової оболонки, призводить до морфологічної перебудови м'язів язика, яка характеризується помірною атрофією, порушенням тканинного та клітинного структурних гомеостазів, зростанням відносного об'єму пошкоджених м'язових волокон, дистрофією, некробіозом та їх контрактурними пошкодженнями. Ступінь ремоделювання м'язів язика домінував у верхньому поздовжньому м'язі язика та у експериментальних тварин старшої вікової групи.

КлючОВІ СЛОВА: десквамативний глосит; язик; м'язи; ремоделювання.

Вступ. Захворювання язика нерідко зустрічаються у клінічній практиці стоматолога, серед яких важливе місце належить десквамативному глоситу. Десквамативний глосит - це запально-дистрофічне ураження слизових оболонки язика, яке локалізується переважно на спинці та бічних поверхнях вказаного органа. Найчастіше дана патологія зустрічається при захворюваннях шлунково-кишкового тракту та кровотворної системи. Десквамативний глосит як самостійна патологія виявляється нерідко, а його діагностика нелегка $[2,3]$.

Необхідно зазначити, що структурні зміни м'язів язика при десквамативному глоситі досліджені недостатньо.

Мета - вивчити вікові особливості ремоделювання м'язів язика при десквамативному глоситі.

Матеріал і методи дослідження. Комплексом морфологічних методів досліджені м'язи язика 60 лабораторних статевозрілих білих щурів-самців, які були поділені на 4-и групи. 1-а група нараховувала 15 8-місячних тварин, які перебували у звичайних умовах віварію, 2-а - 15 аналогічних 24-місячних щурів, 3-я - 15 8-місячних тварин із змодельованим десквамативним глоситом, 4-а - 15 24-місячних щурів із десквамативним глоситом.

Десквамативний глосит моделювали створенням опіків язика оцтовою кислотою [2]. Через 2 тижні від початку досліду виконували евтаназію тварин кровопусканням в умовах тіопенталового наркозу. 3 язика вирізали шматочки, які фіксували у $10 \%$ нейтральному розчині формаліну, проводили через етилові спирти зростаючої концентрації й поміщали у парафінові блоки. Мікротомні зрізи товщиною 5-7 мкм після депарафінізації фарбували гематоксиліном-еозином, за Ван Гізон, Маллорі, Вейгертом, толуїдиновим синім [6].

На гістологічних препаратах язика проводили морфометрію, при якій визначали діаметри м'язових волокон (ДМ), їх ядер (ДЯМ), ядерно-цитоплазматичні відношення у цих структурах (ЯЦВ), відносні об'єми строми (ВОС), м'язів (ВОМ), стромально-міоцитарні відношення (СМВ), відносний об'єм пошкоджених м'язових волокон (ВОПМ) $[1,7]$. Гістологічні препарати досліджували також у поляризованому світлі. 
Огляди літератури, оригінальні дослідження, погляд на проблему, випадок з практики, короткі повідомлення

Морфометрію м'язів язика проводили за допомогою світлового мікроскопа Olimpus BX-2 з цифровою відеокамерою та пакетом прикладних програм «Відео-тест 5,0» та «Відео-розмір 5,0». Статистична обробка отриманих морфометричних показників проведена у відділі системних статистичних досліджень Тернопільського національного медичного університету імені І. Я. Горбачевського МОЗ України у програмному пакеті Statistica. Різницю між порівнювальними величинами визначали за критеріями Стьюдента та Манна - Уїтні [4]. Експериментальні дослідження та евтаназію щурів проводили із дотриманням «Загальних етичних принципів експериментів на тваринах», ухвалених Першим національним конгресом з біоетики (Київ, 2001) та відповідно до «Європейської конвенції про захист хребетних тварин, що використовуються в дослідних та інших наукових цілях» [5].
Результати й обговорення. Кількісні морфологічні показники м'язів всіх груп спостережень представлені у таблиці 1. Усестороннім аналізом наведених у таблиці даних встановлено, що з віком у м'язах язика проходили помірно атрофічні процеси, що підтверджувалося зменшенням діаметрів м'язових волокон та їх ядер при збереженні стабільності ядерно-цитоплазматичних відношень. При десквамативному глоситі досліджувані морфометричні параметри виражено змінювалися. Так, діаметр м'язових волокон неушкодженого язика у 8-місячних лабораторних білих щурів-самців дорівнював $(13,60 \pm 0,12)$ мкм, а при десквамативному глоситі - $(12,44 \pm 0,09)$ мкм. Між наведеними кількісними морфологічними показниками встановлена статистично достовірна різниця ( $<<0,001)$. При цьому останній морфометричний параметр виявився меншим за аналогічний контрольний на $8,5 \%$, а у 24-місячних тварин - на $14,4 \%$ (р<0,001).

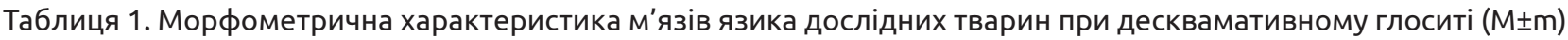

\begin{tabular}{|c|c|c|c|c|}
\hline \multirow{2}{*}{ Показник } & \multicolumn{4}{|c|}{ Група спостережень } \\
\hline & 1 & 2 & 3 & 4 \\
\hline ДМ, МКМ & $13,60 \pm 0,12$ & $12,90 \pm 0,12 * * *$ & $12,44 \pm 0,09 * * *$ & $11,04 \pm 0,06 * * *$ \\
\hline ДЯ, мКм & $3,100 \pm 0,018$ & $2,900 \pm 0,018 * * *$ & $3,050 \pm 0,015^{*}$ & $2,750 \pm 0,015^{* *}$ \\
\hline ЯЦВ & $0,052 \pm 0,002$ & $0,050 \pm 0,002$ & $0,060 \pm 0,002^{*}$ & $0,062 \pm 0,002 * *$ \\
\hline $\mathrm{BOC}, \%$ & $0,110 \pm 0,001$ & $0,116 \pm 0,002^{*}$ & $0,130 \pm 0,002 * *$ & $0,145 \pm 0,003 * * *$ \\
\hline BOM, \% & $0,890 \pm 0,006$ & $0,884 \pm 0,005$ & $0,870 \pm 0,005^{*}$ & $0,855 \pm 0,004^{* *}$ \\
\hline CMB & $0,122 \pm 0,001$ & $0,130 \pm 0,002^{*}$ & $0,150 \pm 0,002^{* * *}$ & $0,170 \pm 0,003^{* * *}$ \\
\hline ВОПМ, \% & $2,10 \pm 0,02$ & $2,50 \pm 0,02 * * *$ & $12,40 \pm 0,15^{* * *}$ & $19,60 \pm 0,18^{* * *}$ \\
\hline
\end{tabular}

Примітка. * $-p<0,05 ; * *-p<0,01 ; * * *-p<0,001$.

Морфометричні параметри ядер досліджуваних структур також змінювалися. У даних експериментальних умовах вказаний кількісний морфологічний показник дорівнював $(3,050 \pm 0,015)$ мкм. Наведений морфометричний параметр виявився на 2,0\% $(p<0,05)$ меншим, порівняно з аналогічним контрольним - $(3,100 \pm 0,018)$ мкм. У тварин старшої вікової групи досліджуваний параметр зменшився на 5,2\% ( $p<0,001)$.

В умовах змодельованої експериментальної патології суттєво порушувалися ядерно-цитоплазматичні відношення у м'язових волокнах язика. Так, у контрольних спостереженнях вказаний морфометричний параметр дорівнював $(0,052 \pm 0,002)$, а при десквамативному глоситі у 8-місячних щурів досліджуваний показник статистично достовірно ( $<<0,05)$ зріс на $15,4 \%$, а у 24-місячних тварин - на 24,0 \% (p<0,01). Наведене свідчить про порушення клітинного структурного гомеостазу $[1,7,8]$.

Відносний о6'єм строми у м'язах язика у 8-місячних тварин при десквамативному глоситі збільшився з $(0,110 \pm 0,001)$ до $(0,130 \pm 0,002)$, тобто на $11,8 \%(p<0,01)$, а у тварин старшої вікової групи - на 25,0 \% ( $<<0,001)$. У даних експериментальних умовах відносний об'єм м'язових структур у молодих тварин статистично достовірно $(p<0,05)$ зменшився на 2,2 \%, а у старих - на 3,3\% $(p<0,01)$. Описані зміни строми та м'язових волокон призводили до порушень стромально-міоцитарних відношень, які при десквамативному глоситі у 8-місячних тварин з вираженою статистично достовірною різницею $(p<0,001)$ зросли 3 $(0,122 \pm 0,001)$ до $(0,150 \pm 0,002)$, тобто на $22,9 \%$, а у щурів старшої вікової групи - на 30,7 \% ( $<<0,001)$. Виявлене вказувало на порушення тканинного структурного гомеостазу [1,7].

При змодельованому десквамативному глоситі у 8-місячних щурів відносний об'єм пошкоджених м'язових волокон з високою статистично достовірною різницею ( $<0,001)$ зріс з $(2,10 \pm 0,02) \%$ до $(12,40 \pm 0,15) \%$, тобто у 5,9 раза, а у 24-місячних тварин - у 7,8 раза ( $<<0,001)$.

Гістологічно у слизовій оболонці язика при десквамативному глоситі відмічалися судинні розлади з домінуванням венозного повнокров'я, 
Огляди літератури, оригінальні дослідження, погляд на проблему, випадок з практики, короткі повідомлення дистрофічні, некробіотичні зміни епітеліоцитів, осередки клітинної інфільтрації та склерозу. Крім описаних морфологічних змін у слизовій оболонці язика, при десквамативному глоситі спостерігалися також структурні зміни у його м'язах.

М'язи язика мають класичну будову скелетних м'язів. Світлооптично у м'язах язика при змодельованій патології спостерігали виражені судинні розлади, які ускладнювалися дезорганізацією структурних компонентів м'язових волокон, зменшенням посмугованості, розволокненістю, розрихленням та розривами. Вяивляли їх звивистість та дистопію локалізації ядер. У деяких м'язових волокнах спостерігали слабоеозинофільну цитоплазму без ядер, що вказувало на цитоліз [6]. Відмічалися поодинокі осередки з явищами некрозу з локалізацією ядер у міжклітинному просторі, а також фрагментація м'язових волокон. У таких осередках візуалізувалося скупчення лімфоцитів. Набряк периваскулярної строми поєднувався з проліферацією сполучнотканинних структур.

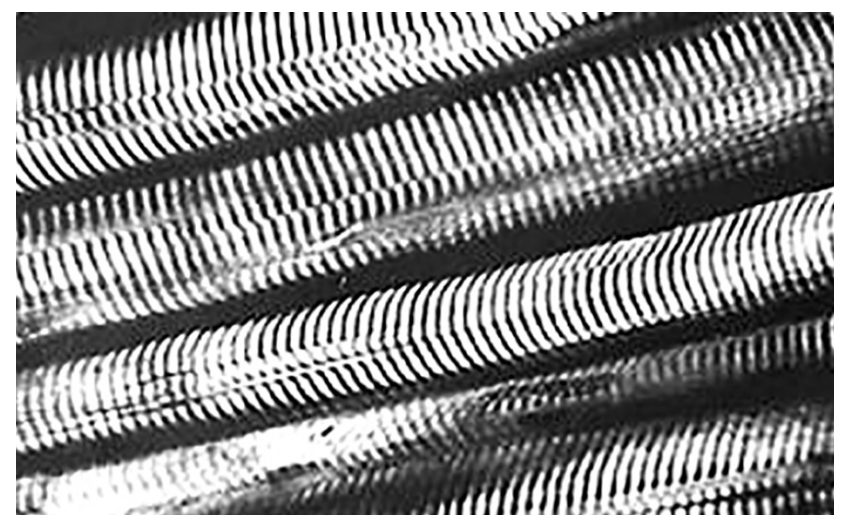

Рис. 1. М'язові волокна неушкодженого язика лабораторного білого щура-самця контрольної групи. Мікропрепарат, забарвлений гематоксиліном-еозином, у поляризованому світлі. Ок.×10, о6. ×20.

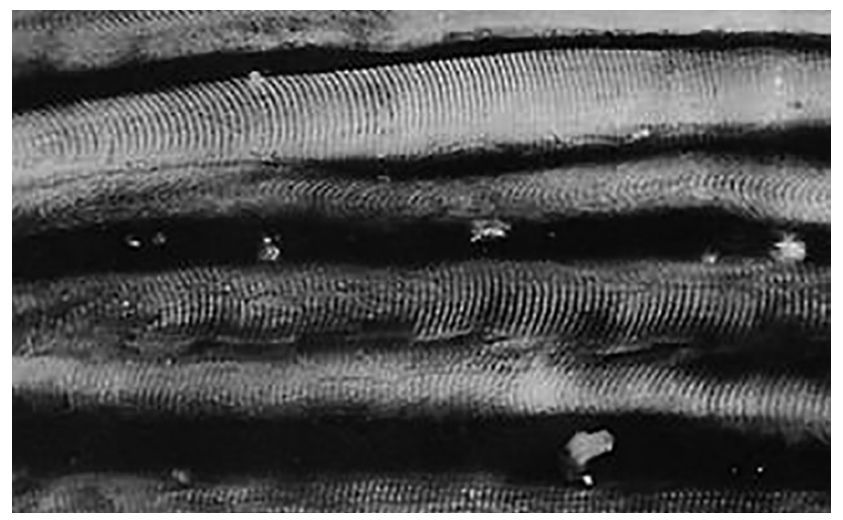

Рис. 2. Ущільнення А-дисків та посилена анізотропія, осередки контрактурних пошкоджень м'язових волокон язика 8-місячної дослідної тварини з десквамативним глоситом. Забарвлений гематоксиліном-еозином мікропрепарат у поляризованому світлі. Ок. ×10, о6. ×20.

При дослідженні м'язових волокон у поляризованому світлі виявляли переважно два види змін міофібрил: перший з них характеризувався контрактурами міофібрилярного апарата, а другий - його лізисом. Для першого виду характерне посилення анізотропії А-дисків, їх ущільнення за рахунок вкорочення ізотропних дисків. При лізисі міофібрилярного апарату в поляризованому світлі спостерігається виражене зниження анізотропії А-дисків, зникнення анізотропної субстанції в межах окремих осередків деяких м'язових волокон. Виявлялися також осередки суцільної анізотропії та розпаду м'язових волокон на окремі фрагменти. Дослідження мікропрепаратів язика в поляризованому світлі свідчило про різний ступінь контрактурних пошкоджень міофібрилярного апарату м'язових волокон (рис. 1-3). Варто вказати, що морфологічні зміни у м'язах язика у 24-місячних щурів при десквамативному глоситі виявилися більш вираженими, ніж у тварин молодшої вікової групи (рис. 3).

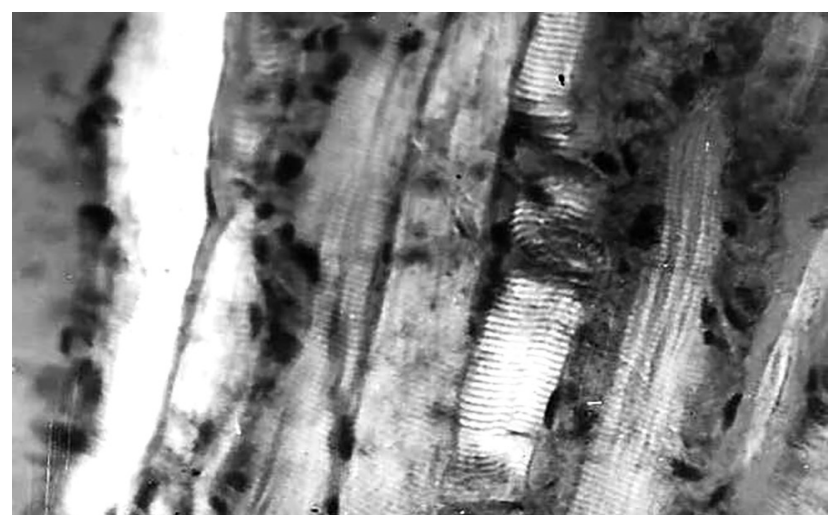

Рис. 3. Контрактури і фрагментований розпад м'язових волокон язика, осередки дифузної анізотропії 24-місячного лабораторного білого щура-самця при десквамативному глоситі. Мікропрепарат, забарвлений гематоксиліном-еозином, у поляризованому світлі. Ок. ×7, о6. ×40.

Поляризоване світло суттєво розширює можливості морфолога і виявляє структурні зміни м'язів язика, які не візуалізуються при світлооптичному дослідженні. Необхідно зазначити, що виявлені структурні зміни домінували у верхньому поздовжньому м'язі язика, який локалізований безпосередньо під його слизовою оболонкою та у тварин старшої вікової групи.

Висновки. Десквамативний глосит у лабораторних білих щурів-самців, крім ремоделювання структур слизової оболонки, призводить до морфологічної перебудови м'язів язика, яка характеризується помірною атрофією, порушенням тканинного та клітинного структурних гомеостазів, зростанням відносного об'єму пошкоджених м'язових волокон, дистрофією, некробіозом та кон- 
Огляди літератури, оригінальні дослідження, погляд на трактурними пошкодженнями. Ступінь ремоделювання м'язів язика домінував у верхньому поздовжньому м'язі язика та у експериментальних тварин старшої вікової групи.

Перспективи подальших досліджень. Всебічне та адекватне вивчення вікових особливос-

\section{ЛІТЕРАТУРА}

1. Автандилов Г. Г. Основы количественной патологической анатомии / Г. Г. Автандилов. - М. : Медицина, 2002. -240 c.

2. Герасимюк І. $€$. Морфофункціональні зміни та просторова характеристика судинного русла язика при його опіках різного генезу в експерименті / І. Є. Герасимюк, О. А. Федорович // Галицький лікарський вісник. 2013. - Т. 20, № 1. - С. 26-29.

3. Данилевський М. Ф. Захворювання слизової оболонки порожнини рота / М. Ф. Данилевський, А. В. Борисенко, М. Ю. Антоненко. - К. : Медицина, 2010. - 640 с.

4. Лапач С. Н. Статистические методы в медицинских исследованиях Excell / С. Н. Лапач, А. В. Губенко, П. Н. Бабич. -К. : Морион, 2001. - 410 с.

\section{REFERENCES}

1. Avtadnilov, G.G. (2002). Osnovy kolichestvennoy patologicheskoy anatomii [Basis of quantitative pathological anatomy]. Moscow: Meditsyna [in Russian].

2. Herasymiuk, I.Ye., \& Fedorovych, O.A. (2013). Morfofunktsionalni zminy ta prostorova kharakterystyka sudynnoho rusla yazyka pry yoho opikakh riznoho henezu v eksperymenti [Morfofunctional changes and spatial characteristics of the vascular bed of the tongue with its burns of different genesis in the experiment]. Halytskyi likarskyi visnyk - Galician Medicinal Herald, 20 (1), 26-29 [in Ukrainian].

2. Danilevskyi, M.F., Borysenko, A.V., \& Antonenko, M.U. (2010). Zakhvoriuvania slyzovoi obolonky porozhnyny rota [Diseases mucosa of mouth]. Kyiv: Medytsyna [in Ukrainian].

3. Sorochinnikov, A.G., Dorosyevich, A.Ye. (2007). Gistologichieskaya i mikroskopicheskaya tekhnika [Histological and microscopic equipments]. Moscow: Meditsyna [in Russian].

4. Lapach, S.N., Gubenko, A.V., \& Babich, P.N. (2001). Statistichieskiye metody $v$ mediko-biologicheskikh issledoтей ремоделювання м'язів язика при десквамативному глоситі дозволить суттєво розширити діагностику, корекцію та профілактику вказаного захворювання.
5. Резніков О. Г. Загальні етичні принципи експериментів на тваринах / О. Г. Резников // Ендокринологія. 2003. - № 1 (8). - С. 142-145.

6. Сорочинников А. Г. Гистологическая и микроскопическая техника / А. Г. Сорочинников, А. Е. Доросевич. - М. : Медицина, 2007. - 448 с.

7. Татарчук Л. В. Морфометричний аналіз особливостей структурної перебудови артерій клубової кишки при пострезекційній портальній гіпертензії / Л. В. Татарчук, М. С. Гнатюк // Здобутки клінічної та експериментальної медицини. - 2018. - № 2. - С. 116-121.

8. Madamandechi N. R. Oxidative stress and vascular disease / N. R. Madamandechi, A. Vendrov, M. R. Runge // Arteriosclerosis. Thrombosis. Vascular Biology. - 2015. Vol. 25. - P. 29-38.

vaniyakh Excell [Statistical methods in medicobiological investigations Excell]. Kyiv: Morion [in Russian].

5. Reznitsov, O.H. (2003). Zahalni etychni pryntsypy eksperymentiv na tvarynakh [General ethical principles of experiments on animals]. Endokrynolohiia-Endocrinology, 8, 1, 142-145 [in Ukrainian].

7. Tatarchuk, L.V., \& Hnatiuk, M.S. (2018). Morphometrychnyi analiz osoblyvostei strukturnoi perestroiky arterii klubovoi kyshky pry postresektsiinii portalnii hypertenzii [Morphometrical analysis pecualiarities structural reconstruction arteries of ileum at postresection portal hypertension]. Zdobutky klinichnoi ta eksperymentalnoi meditsyny Achievements of Clinical and Experimental Medicine, 2, 116121 [in Ukrainian].

8. Madamandechi, N.R, Vendrov, A., Runge, M.R. (2015). Oxidative stress and vascular disease Arteriosclerosis. Thrombosis. Vascular Biology, 25, 29-38.

\title{
ВОЗРАСТНЫЕ ОСОБЕННОСТИ РЕМОДЕЛИРОВАНИЯ МЫШЦ ЯЗЫКА У ЭКСПЕРИМЕНТАЛЬНЫХ ЖИВОТНЫХ ПРИ ДЕСКВАМАТИВНОМ ГЛОССИТЕ
}

\author{
○И. В. Боднарчук, М. С. Гнатюк, Л. В. Татарчук
}

Тернопольский национальный медицинский университет имени И. Я. Горбачевского МОз Украины

РЕзЮМЕ. Десквамативный глоссит - это воспалительно-дистрофическое поражение слизистой оболочки языка, которое локализуется преимущественно на спинке и боковых поверхностях названного органа. Наиболее часто указанная патология встречается при заболеваниях желудочно-кишечного тракта и кроветворной системы. Десквамативный глоссит как самостоятельная патология случается нередко, а его диагностика нелегкая. 
Огляди літератури, оригінальні дослідження, погляд на проблему, випадок з практики, короткі повідомлення

Цель - изучение возрастных особенностей ремоделирования мышц языка при десквамативном глоссите.

Материал и методы. Комплексом морфологических методов исследованы мышцы языка 60 лабораторных половозрелых белых крыс-самцов, которые были поделены на четыре группы. 1-я группа насчитывала 15 8-месячных животных, которые находились в обычных условиях вивария, 2-я - 15 аналогичных 24-месячных крыс, 3-я - 15 8-месячных животных со смоделированным десквамативным глосситом, 4-я - 15 24-месячных крыс с такой же смоделированной патологией. Микротомные срезы языка окрашивали гематоксилином-эозином, по Ван Гизон, Маллори, толуидиновым синим. Морфометрически определяли диаметр мышечных волокон, их ядер, ядерно-цитоплазматические соотношения в этих структурах, относительные объемы стромы, мышц, стромальномиоцитарные соотношения, относительный объем поврежденных мышечных волокон. Гистологические препараты исследовали также в поляризованном свете. Количественные показатели обрабатывали статистически.

Результаты. Установлено, что десквамативный глоссит у лабораторных белых крыс-самцов, кроме ремоделирования структур слизистой оболочки, приводит к морфологической перестройке мышц языка, которая характеризуется умеренной атрофией, нарушением тканевого и клеточного структурных гомеостазов, ростом относительного объема поврежденных мышечных волокон, дистрофией, некробиозом и контрактурными повреждениями, инфильтрацией и склерозированием. Степень ремоделирования мышц языка доминировала в верхней продольной мышце и у старых экспериментальных животных. Последнее подтверждалось относительными объемами поврежденных мышечных волокон, который у молодых крыс достигал $(12,40 \pm 0,15) \%$, у старых $(19,60 \pm 0,18) \%(p<0,001)$.

Выводы. Десквамативный глоссит у лабораторных белых крыс-самцов, кроме ремоделирования структур слизистой оболочки, приводит к морфологической перестройке мышц языка, которая характеризуется умеренной атрофией, нарушениями тканевого и клеточного структурных гомеостазов, увеличением относительного объема поврежденных мышечных волокон, дистрофией, некробиозом и контрактурными их повреждениями. Степень повреждения мышц языка доминировала в верхней продольной мышце языка и у старых экспериментальных животных.

КЛЮЧЕВЫЕ СЛОВА: десквамативный глоссит; язык; мышцы; ремоделирование.

\title{
AGE FEATURES OF REMODELING MUSCLES OF TONGUE IN EXPERIMENTAL ANIMALS AT DESQUAMATIVE GLOSSITIS
}

\author{
@I. V. Bodnarchuk, M. S. Hnatjuk, L. V. Tatarchuk \\ I. Horbachevsky Ternopil National Medical University
}

SUMMARY. Desquamative glossitis is an inflammatory and dystrophic lesion of the mucosa of the tongue, which is localized mainly on the back and sides of this organ. Most often this pathology is found in diseases of the gastrointestinal tract and the hematopoetic system. Desquamative glossitis as an independent pathology is often found, and its diagnosis is not easy.

The aim - to study the age-old features of the remodeling of the muscle of the tongue at desquamative glossitis.

Material and Methods. The complex of morphological methods examined the tongue muscles of 60 laboratory mature white male rats, which were divided into 4 groups. The group 1 consisted of 158 -month-old animals that were under normal vivarium conditions, group 2 - 15 the same 24-month-old rats, group 3 - 15 8-month-old animals with simulated desquamative glossitis, group 4-15 24-month-old rats with desquamative glossitis.

The microtomy sections of the tongue were stained with hematoxylin-eosin, for van Gizon, Mallory, and toluidine blue. The diameter of muscle fibers, their nuclei, nuclear-cytoplasmic ratios in these structures, relative volumes of stroma, muscle, stromal-myocyte ratio, relative volume of damaged muscle fibers were Mmorphometrically determined. Histological preparations were also investigated in polarized light. Quantitative indicators were processed statistically.

Results. It was established that desquamative glossitis in laboratory white male rats, in addition to remodeling of the structures of the mucosa, leads to the morphological reorganization of the muscles of the tongue, which is characterized by moderate atrophy, a violation of tissue and cellular structural homeostasis, an increase in the relative volume of damaged muscle fibers, dystrophy, necrobiosis and contracture damage, infiltration and sclerosis. The degree of remodeling of the muscles of the tongue dominated the upper longitudinal muscle and old animal. The latter was confirmed by the relative volumes of damaged muscle fibers, which in young rats was equal $(12.40 \pm 0.15) \%$, and in the old $-(19.60 \pm 0.18) \%(p<0.001)$.

Conclusions. Desquamative glossitis in laboratory white male rats, in addition to remodeling the structures of the mucosa, leads to a morphological alteration of the muscles of the tongue, which is characterized by moderate atrophy, a violation of tissue and cellular structural homeostasis, an increase in the relative volume of damaged muscle fibers, dystrophy, necrobiosis and contractal damage to them. The degree of remodeling of the muscles of the tongue was dominated by the upper longitudinal muscle of the tongue and in the experimental animals of the older age group.

KEY WORDS: desquamative glossitis; tongue; muscles; remodeling. 